\title{
ИНФОРМАЦИОННАЯ СИСТЕМА VOLSATVIЕW ДЛЯ РЕШЕНИЯ ЗАДАЧ МОНИТОРИНГА ВУЛКАНИЧЕСКОЙ АКТИВНОСТИ КАМЧАТКИ И КУРИЛ
}

\author{
(C) 2016 г. Е. И. Гордеев ${ }^{1}$, О. А. Гирина 1 , Е. А. Лупян ${ }^{2}$, А. А. Сорокин ${ }^{3}$, Л. С. Крамарева \\ В. Ю. Ефремов ${ }^{2}$, А. В. Кашницкий ${ }^{2}$ И. А. Уваров ${ }^{2}$, М. А. Бурцев ${ }^{2}$, \\ И. М. Романова ${ }^{1}$, Д. В. Мельников ${ }^{1}$, А. Г. Маневич ${ }^{1}$, С. П. Королев ${ }^{3}$, А. Л. Верхотуров ${ }^{3}$ \\ ${ }^{1}$ Институт вулканологии и сейсмологии Дальневосточного отделения Российской академии наук \\ 683006 Петропавловск-Камчатский, б-р Пийпа, 9 \\ ${ }^{2}$ Институт космических исследований Российской академии наук \\ 117997 Москва, ул. Профсоюзная, 38/32 \\ ${ }^{3}$ Вычислительный центр Дальневосточного отделения Российской академии наук \\ 680000 Хабаровск, ул. Ким Ю Чена, 65 \\ ${ }^{4}$ Дальневосточный центр “Научно-исследовательский центр космической гидрометеорологии Планета" \\ 680673 Хабаровск, ул. Ленина, 18 \\ e-mail:gordeev@kscnet.ru \\ Поступила в редакцию 15.01.2016 г.
}

\begin{abstract}
На Камчатке и Северных Курилах расположено 36 действующих вулканов, ежегодно здесь происходят сильные эксплозивные извержения с выбросом пеплов до 8-15 км над уровнем моря, представляющие реальную угрозу для современной реактивной авиации. Для снижения опасности столкновения самолетов с пепловыми облаками в северной части Тихоокеанского региона, группа KVERT ИВиС ДВО РАН с 2002 г. проводит ежедневный спутниковый мониторинг камчатских вулканов. В 2011-2015 гг. специалистами ИВиС ДВО РАН, ИКИ РАН, ВЦ ДВО РАН и ДЦ НИЦ Планета была создана, введена в эксплуатацию и развивается информационная система "Мониторинг активности вулканов Камчатки и Курил” (VolSatView), позволяющая вулканологам комплексно работать с различными спутниковыми данными, а также метео- и наземной информацией, для непрерывного мониторинга и исследования вулканической активности Курило-Камчатского региона. Таких возможностей как в VolSatView в настоящее время нет ни в одной информационной системе мира, работающей в направлении исследования вулканов. В работе показаны основные возможности применения VolSatView для решения задач оперативного мониторинга и ретроспективного анализа активности вулканов Камчатки и Курил.
\end{abstract}

DOI: $10.7868 / \mathrm{S} 0203030616060043$

\section{ВВЕДЕНИЕ}

На Камчатке и Северных Курилах расположено 36 действующих вулканов, от двух до восьми из которых ежегодно извергаются, поставляя в атмосферу тонны вулканического пепла, газа и аэрозолей. Кроме этого, ежегодно здесь происходят сильные эксплозивные события, при которых пеплы поднимаются до 8-15 км над уровнем моря (н.у.м.), представляя существенную опасность для полетов современной реактивной авиации [Гирина, 2012; Гирина, Гордеев, 2007; Гордеев, Гирина, 2014; Miller, Casadevall, 2000; Neal et al., 2009].

Для уменьшения риска столкновения самолетов с пепловыми облаками в различных странах мира, где имеются действующие вулканы, созданы вулканологические обсерватории для проведения мониторинга хотя бы части таких вулка- нов. Проблема в том, что на нашей планете насчитывается более 800 действующих вулканов, но осушествлять непрерывное слежение за каждым из них не представляется возможным даже в развитых странах. Например, на территории Японии расположено 83 действующих вулкана, но лишь для 19 из них существует непрерывный мониторинг. Координацию работы 79 вулканологических обсерваторий мира осушествляет Всемирная организация вулканологических обсерваторий (World Organization of Volcano Observatories - WOVO, http://www.wovo.org), действующая при Международной ассоциации вулканологии и химии недр Земли (International Association of Volcanology and Chemistry of the Earth's Interior - IAVCEI, http://www.iavcei.org/). WOVO издает справочник, содержащий сведения о размещении вулканологи- 
ческих обсерваторий в государствах, об их программах слежения за вулканами, контактную информацию ответственных за выполнение программ вулканологов и т.д. Различные вулканологические обсерватории используют все или некоторые из методов слежения за вулканами: видео и визуальный, геофизический (анализ сейсмических, электрических, магнитных, гравитационных и других явлений), гидрологический, газовый, спутниковый (анализ различных, в том числе интерферометрических данных) и др. Для объединения усилий различных служб (вулканологических обсерваторий; метеорологических, гидрологических и других станций; и т.п.) по обнаружению вулканического пепла в атмосфере и непрерывному слежению за его перемещением для снижения опасности для авиаперевозок, Международная организация гражданской авиации (International Civil Aviation Organization - ICAO, http://www.icao.int) назначила девять специализированных метеорологических центров в качестве консультационных центров по вулканическому пеплу (Volcanic Ash Advisory Centers - VAAC: Анкоридж, Буэнос-Айрес, Вашингтон, Веллингтон, Дарвин, Лондон, Монреаль, Токио, Тулуза) и определила границы их ответственности. Кроме этого, в рамках глобального спутникового мониторинга вулканов созданы web-порталы, представляющие отдельные направления исследований, например: Спутниковый мониторинг активных вулканов восточной Азии близко к реальному времени (Near Realtime Monitoring of Active Volcanoes in East Asia using Satellite Data, http://vrsserv.eri.u-tokyo.ac.jp/REALVOLC/); Система детектирования вулканических горячих точек близко к реальному времени (Near Real Time Volcanic HotSpot Detection System, http://www.mirovaweb.it/); Мониторинг вулканических облаков (the NOAA/CIMSS Volcanic Cloud Monitoring Web Portal, https://volcano.ssec.wisc.edu/); Система оповещения о вулканическом пепле и $\mathrm{SO}_{2}$ в рамках Службы поддержки авиации (Support Aviation Control Service (SACS) $\mathrm{SO}_{2}$ \& Ash Notification System, http://sacs.aeronomie.be/).

Для повышения безопасности авиаполетов при эксплозивных извержениях вулканов в 1993 г. на Камчатке была создана Камчатская группа реагирования на вулканические извержения (KVERT Kamchatkan Volcanic Eruption Response Team, http://www.kscnet.ru/ivs/kvert/), которая с 2010 г., как часть Института вулканологии и сейсмологии (ИВиС) ДВО РАН, выполняет функции вулканологической обсерватории Российской Федерации (WOVO № 290111-300001) по обеспечению информацией о вулканической деятельности на Дальнем Востоке международного аэронавигационного сообщества [Гирина, 2012; Гордеев, Гирина, 2014; Кирьянов и др., 2001; Miller, Casadevall, 2000; Neal et al., 2009]. Целью KVERT является уменьшение риска столкновения самолетов с пепловыми облаками в северной части Тихоокеанского региона с помощью своевременного обнаружения повышения активности вулканов, распознавания и отслеживания облаков вулканического пепла, и оперативного оповещения администраций авиакомпаний о появлении опасности, связанной с вулканическим пеплом. Для этого ученые из группы KVERT анализируют данные сейсмического мониторинга вулканов Камчатского филиала Геофизической службы (КФ ГС) РАН; видео- и визуальную информацию о состоянии вулканов, поступающую из различных источников (от геологов, метеорологов, пилотов, туристов, альпинистов и др.). Спутниковый мониторинг вулканов для отслеживания перемещений пепловых шлейфов и облаков при извержениях вулканов Шивелуч и Безымянный сотрудники группы KVERT начали применять с 1993 г. (спутниковые данные NOAA 11 и 12 предоставила Национальная администрация океанографии и атмосферы (National Oceanic and Atmospheric Administration NOAA), США; и Метеор-21 - Камчатская гидрометеослужба России) [Гирина, 2008; Кирьянов и др., 2001]. Возможности спутникового мониторинга вулканов Камчатки с течением времени расширялись: например, если в 1997 г. KVERT получал снимки NOAA на территорию Камчатки по факсимильной связи из Аляскинской вулканологической обсерватории (АВО) США, и с 1998 г. до 17 мая 2013 г. из ABO в KVERT два раза в сутки поступали информационные бюллетени с результатами обработки всех возможных спутниковых данных, то с 1999 г., со времени предоставления ABO доступа KVERT к спутниковым снимкам NOAA, и до настоящего времени сотрудники группы KVERT самостоятельно проводят спутниковый мониторинг вулканов Камчатки и Северных Курил (обрабатывают и анализируют спутниковые данные) [Гирина, 2008, 2012, 2014].

KVERT поддерживает долговременные связи с различными организациями, предоставляющими спутниковые данные: например, с сентября 2002 г. получает и интерпретирует снимки MODIS (Moderate Resolution Imaging Spectroradiometer) из ДФ ФГУНПП “Росгеолфонд”; с 2009 г. сотрудничает с ФГБУ “Камчатское УГМС”; в 20072009 гг. сотрудники группы KVERT обрабатывали и анализировали исходные снимки TERRA и AQUA (MODIS) и NOAA (AVHRR), поступавшие из ДЦ НИЦ Планета [Гирина, 2008, 2014].

Ежедневный оперативный спутниковый мониторинг камчатских вулканов ученые из группы KVERT проводят с 2002 г. [Гирина, 2012, 2014; Гордеев, Гирина, 2014; Neal et al., 2009]. Необходимость такого мониторинга обусловлена следующими причинами: расположение многих активных вулканов в труднодоступных районах, далеко от населенных пунктов; отсутствие сейсмических станций на большинстве активных вулканов (на- 
пример, на Камчатке сейсмостанции имеются только на десяти из тридцати активных вулканов); необходимость получения ежедневной оперативной информации по состоянию вулканов и авиатрасс, пролегающих в Курило-Камчатском регионе (пепловые выбросы могут распространяться на тысячи километров в различных направлениях от вулканов, создавая препятствия для авиаполетов) и т.д.

Оперативный спутниковый мониторинг вулканов (обработка спутниковых данных по мере их поступления) включает в себя:

- обнаружение пепловых облаков и шлейфов, определение их параметров (длина, площадь и азимут распространения);

- детектирование термальных аномалий в районах вулканов, определение их параметров (размер, температура аномалии и фона);

- выпуск оперативных сообщений Volcano Observatory Notice for Aviation (VONA) об обнаружении пепловых шлейфов в районах вулканов и/или о прогнозе эксплозивного извержения, опасного для населения и авиации;

- размещение VONA и данных оперативного спутникового мониторинга в базе данных KVERT "Активность вулканов Камчатки и Северных Курил"; публикация VONA на сайте KVERT (http://www.kscnet.ru/ivs/kvert/van/) и в информационной системе (ИС) "Вулканы Курило-Камчатской островной дуги" (VOKKIA) Геопортала ИВиС ДВО РАН (http://geoportal.kscnet.ru/volcanoes/van/ ).

Ретроспективный анализ активности вулканов с помощью спутниковых данных предполагает детальное исследование вулканогенных продуктов и определение их параметров (например, изменение площадей, объемов и направления перемещения пепловых шлейфов и лавовых потоков в течение извержений; изменение площадей и объемов отложений пирокластических потоков вулкана, а также изменение направления перемещения таких потоков во время различных извержений и т.д.) для оценки динамики активности вулканов с течением времени (частота эксплозивных извержений каждого вулкана; изменение количества энергии, поступающей на поверхность земли при извержениях вулканов, косвенным показателем которой являются объемы изверженных продуктов) и прогноза возможной будущей опасности вулканов для населения.

По различным причинам потоки спутниковой информации, доступные сотрудникам группы KVERT для обработки и анализа, постоянно менялись, для корректной оценки вулканоопасности для населения полуострова и авиации требовался устойчивый источник спутниковых данных.

Очевидно, что частота и качество поступающей спутниковой информации напрямую влияет на корректность оценки опасности вулканической активности в регионе и достоверность прогноза ее развития в будущем. Основными принципами организации спутникового мониторинга должны быть следующие:

- максимальная частота поступления спутниковых данных, автоматизация их сбора;

- удобные инструменты для работы с данными;

- возможность удаленной (распределенной) работы с данными;

- возможность совместной работы и анализа спутниковых и иных инструментальных и научных данных (например, видео-, результатов математического моделирования и т.п.), поступающих из других ИС;

- ориентация на свободно распространяемые некоммерческие спутниковые данные, поскольку необходимы очень большие объемы информации.

Для комплексного решения вышеперечисленных задач в 2011 г. совместными усилиями специалистов ИВиС ДВО РАН, Института космических исследований (ИКИ) РАН, Вычислительного центра (ВЦ) ДВО РАН и Дальневосточного научно-исследовательского центра (ДЦ НИЦ) Планета были начаты работы по созданию ИС "Мониторинг активности вулканов Камчатки и Курил” (VolSatView). Система была создана, введена в эксплуатацию и развивается при частичной поддержке грантов РФФИ (проекты 11-0712026-офи_м, 13-07-12180-офи_м).

\section{ИНФОРМАЦИОННАЯ СИСТЕМА VOLSATVIЕW Архитектура системы и основные источники информации}

Основной задачей ИС VolSatView является обеспечение специалистов-вулканологов, занимающихся мониторингом и исследованием вулканической активности Камчатки и Курил, оперативными и архивными спутниковыми и метео данными и информационными продуктами, получаемыми на их основе, а также предоставление различных инструментов для комплексной обработки и анализа вышеуказанной информации совместно с данными, поступающими из других ИС (например, инструменты для проведения оперативного моделирования процессов распространения пепловых шлейфов). В соответствии с задачей была создана архитектура ИC VolSatView (http://volcanoes.smislab.ru), ориентированная на обеспечение работы с распределенными информационными ресурсами и вычислительными системами, использующимися для сбора, обработки, хранения, анализа и представления различной инструментальной и научной информации [Ефремов и др., 2012, 2013, 2013а; Гордеев и др., 2014, 2015; и др.] (рис. 1). Пользователям предоставляется возможность работы с данными, опе- 


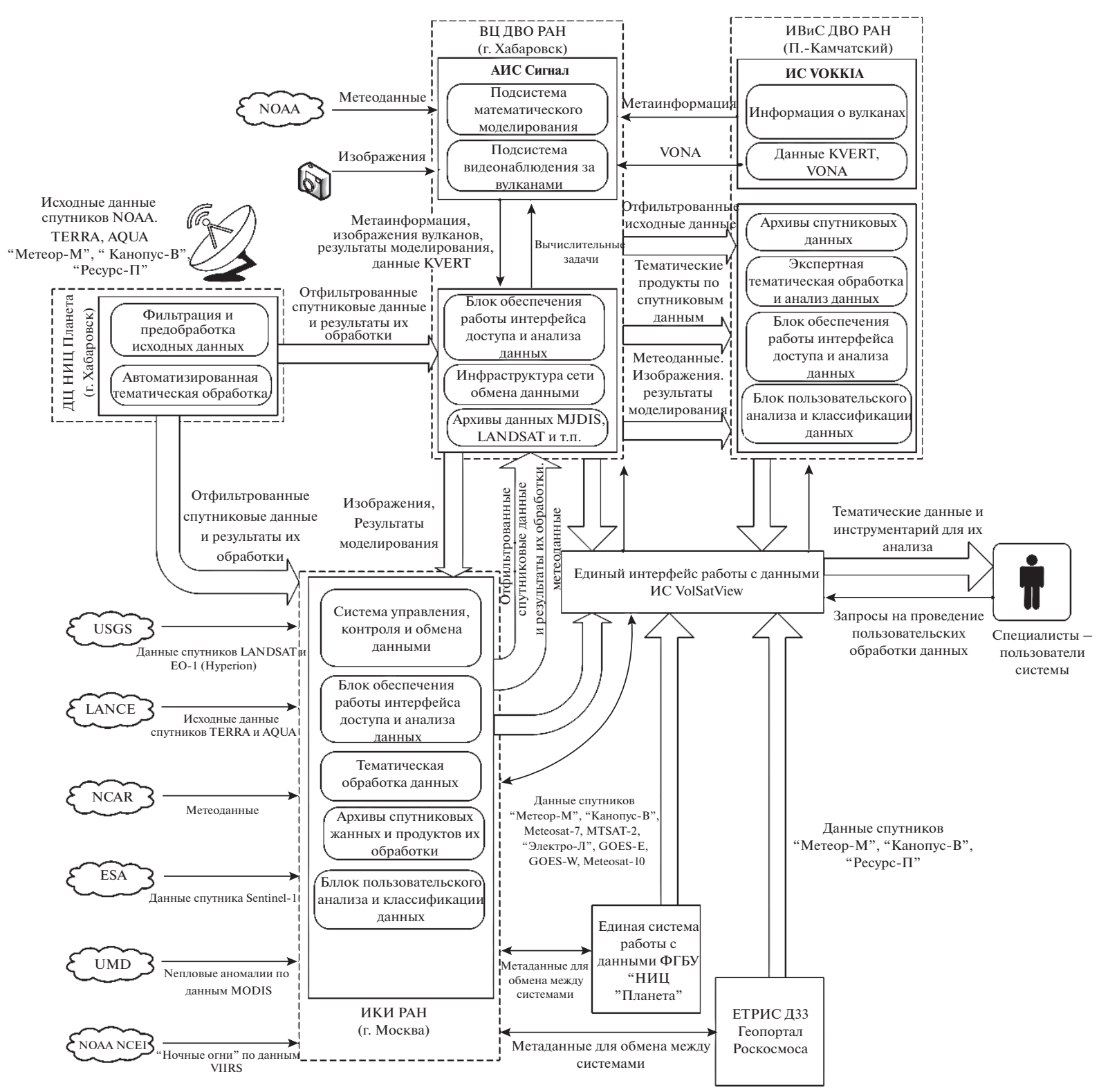

Рис. 1. ИС VolSatView: архитектура системы и потоки данных.

Аббревиатуры: USGS - United States Geological Survey, LANCE - Land, Atmosphere Near real-time Capability, NCAR National Center for Atmospheric Research, ESA - European Space Agency, UMD - University of Minnesota Duluth, NOAA NCEI - National Oceanic and Atmospheric Administration National Centers for Environmental Information (другие см. в тексте статьи).

ративно поступающими из различных источников и информационных ресурсов, а также с историческими архивами информации, накопленной в различных центрах сбора и обработки спутниковых данных. В настоящее время узлы системы размещены в гг. Москва, Хабаровск и Петропавловск-Камчатский, а обмен информацией между ними осушествляется с использованием каналов связи Региональной компьютерной сети ДВО РАН, ИКИ РАН и ДЦ НИЦ Планета [Ефремов и др., 2012; Ханчук и др., 2013; Khanchuk et al., 2010].
Отметим, что одной из основных задач VolSatView является организация доступа пользователей к различным спутниковым данным и возможность автоматического формирования на их основе базовых информационных продуктов, которые могут быть использованы при решении задач мониторинга и изучения вулканической активности. Система обеспечивает возможность работы со следующей спутниковой информацией, поступающей:

- от различных метеорологических спутниковых систем, таких как: NOAA (прибор AVHRR), 
Terra и Aqua (MODIS), Suomi NPP (National Polar-orbiting Partnership) (VIIRS - Visible Infrared Imaging Radiometer Suite), Метеop-M (МСУ-MP многозональное сканирующее устройство малого разрешения); геостационарных (в частности, в ближайшее время планируется организация оперативного потока информации, получаемой с японского геостационарного спутника нового поколения Himawari-8). Эта информация является основой для оперативного мониторинга вулканической активности;

- природоресурсных спутников различного пространственного и спектрального разрешения.

Сегодня в систему поступают данные со спутников Метеор-М (КМСС - комплекс многозональной спутниковой съемки), Landsat 7 (ETM+ - Enhanced Thematic Mapper Plus), Landsat 8 (OLI (Operational Land Imager) и TIRS (Thermal Infrared Sensor)), Канопус-В (MCC (многозональная съемочная система), ПСС (панхроматическая съемочная система)), Ресурс 1 и 2 (Геотон; КШМСА-ВР и КШМСА-СР - широкозахватная многоспектральная аппаратура высокого и среднего разрешения), EO-1 (Earth Observing One Mission) (Hyperion), Sentinel 1A, планируется opганизация работы с данными спутника Sentinel 2А. Эти данные могут поступать в систему с разной периодичностью и временной задержкой.

Возможности системы работать с такой разнообразной спутниковой информацией и результатами ее обработки позволяют использовать ее для решения достаточно широкого круга задач, связанных с мониторингом и изучением вулканической активности (табл. 1). ИС VolSatView комплексностью созданных возможностей не только для мониторинга вулканов, но и изучения вулканогенных явлений и процессов, коренным образом отличается от имеющихся в мире ИС для мониторинга вулканов. Объединяя широкий спектр данных различных спутниковых систем, поступающих из разных источников, и видеонаблюдения вулканов, система позволяет непосредственно в web-интерфейсе с помощью созданных специальных инструментов совместно обрабатывать оперативную и ретроспективную спутниковую информацию, сопоставлять ее с видеоинформацией, выполнять моделирование распространения пепловых шлейфов, классифицировать различные вулканогенные объекты.

В настоящее время по районам Камчатки и Курил в VolSatView данные от различных спутниковых систем поступают около 20 раз в сутки. Достаточно быстрое развитие возможностей спутниковых систем наблюдений может существенно повысить частоту и объемы такого рода данных в ближайшие годы. Частота получения информации особенно важна в связи с быстротечностью различных вулканических процессов, например, распространением пепловых шлейфов при извержениях вулканов. При этом особенно важно обеспечить хорошую сопоставимость данных, принимаемых от различных спутниковых систем. Например, на снимках, полученных с помощью спутников NOAA (AVHRR) и Terra и Aqua (MODIS), явно выделяются пепловые шлейфы по разности инфракрасных (ИК) каналов 10-12 мкм (4-5 каналы AVHRR и 31-32 каналы MODIS) (рис. 2). Данные, полученные разными приборами, показывают хорошую сопоставимость и однотипность информации, что позволяет увеличить частоту наблюдений за распространением пепловых шлейфов, которые, в зависимости от мощности и высоты пепловых выбросов, а также скорости и направления ветра на разных высотах, могут перемещаться на сотни и тысячи километров от вулкана, представляя угрозу населению полуострова и пассажирам авиалайнеров. Повышение частоты наблюдений за распространением пепловых шлейфов и оперативное оповещение заинтересованных пользователей об их перемещении позволяют заранее предупредить население об опасности пеплопадов и снизить угрозу попадания самолетов в пепловые облака.

Следует отметить, что для повышения оперативности получения спутниковой информации организовано ее поступление непосредственно из центра приема и обработки спутниковых данных ДЦ НИЦ Планета (http://www.dvrcpod.ru/), который на сегодняшний день является крупнейшим из таких центров в Дальневосточном регионе.

VolSatView обеспечивает работу не только с оперативно поступающими спутниковыми данными, но и с историческими архивами спутниковой информации по территории Камчатки и Курил. В частности, пользователи системы имеют возможность работы с данными, полученными еще в восьмидесятые годы двадцатого столетия. Кроме этого, в системе доступны однородные архивы различной спутниковой информации (например, данные о термальных аномалиях, наблюдавшихся в районах действующих вулканов с 2000 г.). Основным источником исторических данных в системе являются архивы, накопленные в ИКИ PAH (http://iki.rssi.ru/) и ДВ НИЦ Планета (http://www.dvrcpod.ru/) [Лупян и др., 2014]. Кроме того, в системе имеется возможность работы с данными Геопортала Роскосмоса (http://gptl.ru/). Наряду со спутниковыми данными в VolSatView доступна оперативная метеоинформация и ее архивы с 2000 г., накопленные в ИКИ РАН и ДЦ НИЦ Планета.

\section{Инструменты для работы с данными}

Одной из важных задач ИC VolSatView является обеспечение специалистов вулканологов инструментами для анализа данных. Выполнение 
Таблица 1. Спутниковые данные для мониторинга вулканической активности Камчатки и Курил в ИC VolSatView

\begin{tabular}{|c|c|c|c|}
\hline Задачи & $\begin{array}{l}\text { Спутники } \\
\text { (приборы) }\end{array}$ & $\begin{array}{c}\text { Анализ данных созданными } \\
\text { в ИС инструментами }\end{array}$ & $\begin{array}{l}\text { Количество } \\
\text { снимков } \\
\text { в сутки, ед. }\end{array}$ \\
\hline \multicolumn{4}{|c|}{ Оперативный мониторинг активности вулканов } \\
\hline \multirow{3}{*}{$\begin{array}{l}\text { Детектирование } \\
\text { термальных аномалий }\end{array}$} & NOAA (AVHRR) & \multirow{3}{*}{$\begin{array}{l}\text { Выделение аномалий и измере- } \\
\text { ние их размера и температуры }\end{array}$} & 15 \\
\hline & Terra/Aqua (MODIS) & & 4 \\
\hline & Suomi NPP (VIIRS) & & 4 \\
\hline \multirow{3}{*}{$\begin{array}{l}\text { Обнаружение пепловых облаков } \\
\text { и шлейфов }\end{array}$} & NOAA (AVHRR) & \multirow{3}{*}{$\begin{array}{l}\text { Выделение пепловых шлейфов } \\
\text { и измерение их направления } \\
\text { перемещения (азимут), протя- } \\
\text { женности, площади }\end{array}$} & 15 \\
\hline & Terra/Aqua (MODIS) & & 4 \\
\hline & Suomi NPP (VIIRS) & & 4 \\
\hline $\begin{array}{l}\text { Обнаружение лавовых потоков, } \\
\text { пирокластических потоков, обва- } \\
\text { лов, оползней на склонах вулканов }\end{array}$ & $\begin{array}{l}\text { Terra/Aqua (MODIS); } \\
\text { Канопус-B (MCC, ПCC); } \\
\text { Метеор-M (KMCC); } \\
\text { Landsat (ETM+, OLI, TIRS); } \\
\text { EO-1 (Hyperion) }\end{array}$ & \multicolumn{2}{|c|}{$\begin{array}{l}\text { Определение характеристик отложений (мощ- } \\
\text { ность, площадь, объем), оценка активности } \\
\text { вулканов }\end{array}$} \\
\hline \multicolumn{4}{|c|}{ Ретроспективный анализ активности вулканов } \\
\hline $\begin{array}{l}\text { Анализ распределения темпера- } \\
\text { туры в пределах термальных } \\
\text { аномалий }\end{array}$ & $\begin{array}{l}\text { Terra/Aqua (MODIS); } \\
\text { Landsat (ETM+, OLI, TIRS); } \\
\text { EO-1 (Hyperion) }\end{array}$ & \multicolumn{2}{|l|}{$\begin{array}{l}\text { Выявление зональности } \\
\text { в распределении температуры } \\
\text { в пределах аномалии }\end{array}$} \\
\hline $\begin{array}{l}\text { Анализ изменения параметров } \\
\text { аномалий (размер, температура) } \\
\text { на вулканах с течением времени }\end{array}$ & $\begin{array}{l}\text { NOAA (AVHRR); } \\
\text { Terra/Aqua (MODIS); } \\
\text { Suomi NPP (VIIRS) }\end{array}$ & \multicolumn{2}{|c|}{$\begin{array}{l}\text { Сопоставление изменения параметров анома- } \\
\text { лий с эруптивной активностью вулканов }\end{array}$} \\
\hline $\begin{array}{l}\text { Анализ изменений направлений } \\
\text { распространения пепловых } \\
\text { шлейфов за интервалы времени } \\
\text { (годы, месяцы) }\end{array}$ & $\begin{array}{l}\text { NOAA (AVHRR); } \\
\text { Terra/Aqua (MODIS); } \\
\text { Suomi NPP (VIIRS) }\end{array}$ & \multicolumn{2}{|c|}{$\begin{array}{l}\text { Сопоставление изменений направлений рас- } \\
\text { пространения пепловых шлейфов с динами- } \\
\text { кой и мощностью извержений }\end{array}$} \\
\hline $\begin{array}{l}\text { Анализ изменений отложений } \\
\text { лавовых потоков, пирокластиче- } \\
\text { ских потоков, обвалов, оползней } \\
\text { с течением времени }\end{array}$ & $\begin{array}{l}\text { Terra/Aqua (MODIS); } \\
\text { Канопус-В (MCC, ПСС); } \\
\text { Метеop-M (KMCC); } \\
\text { Landsat (ETM+, OLI, TIRS); } \\
\text { EO-1 (Hyperion) }\end{array}$ & \multicolumn{2}{|c|}{$\begin{array}{l}\text { Сопоставление изменений отложений (мощ- } \\
\text { ность, площадь, объем) с динамикой изверже- } \\
\text { ний, оценка активности вулканов }\end{array}$} \\
\hline
\end{tabular}

базовых операций с данными в VolSatView peaлизовано на основе технологии GeoSmis [Андреев и др., 2004; Балашов и др., 2013; Егоров и др., 2004; Ефремов и др., 2004, 2012; Лупян и др., 2004, 2011; Толпин и др., 2011; Уваров и др., 2013, 2014]. Созданные web-интерфейсы решают задачи унификации представления разнотипных данных, поступающих из различных информационных систем и ресурсов, а также позволяют выполнять подбор необходимых наборов данных, их обработку и анализ. В системе реализован достаточно широкий набор инструментов для работы как с рядами наблюдений, так и с картографической информацией (от представления данных в различных проекциях до анализа спектральных ха- рактеристик, получаемых с использованием гиперспектральных данных, и проведением классификации данных).

Также в системе ведется разработка ряда специальных средств и технологий, ориентированных на решение задач, возникающих при мониторинге и изучении вулканической активности [Ефремов и др., 2012; Гордеев и др., 2014, 2015; и др.]. Непосредственно в web-интерфейсе ИС VolSatView доступны инструменты для анализа полей температуры, позволяющие мгновенно просматривать значения температуры (в градусах Цельсия или Кельвина) в каждой точке снимка, что значительно сокращает время анализа термальных аномалий в районах действующих вул- 


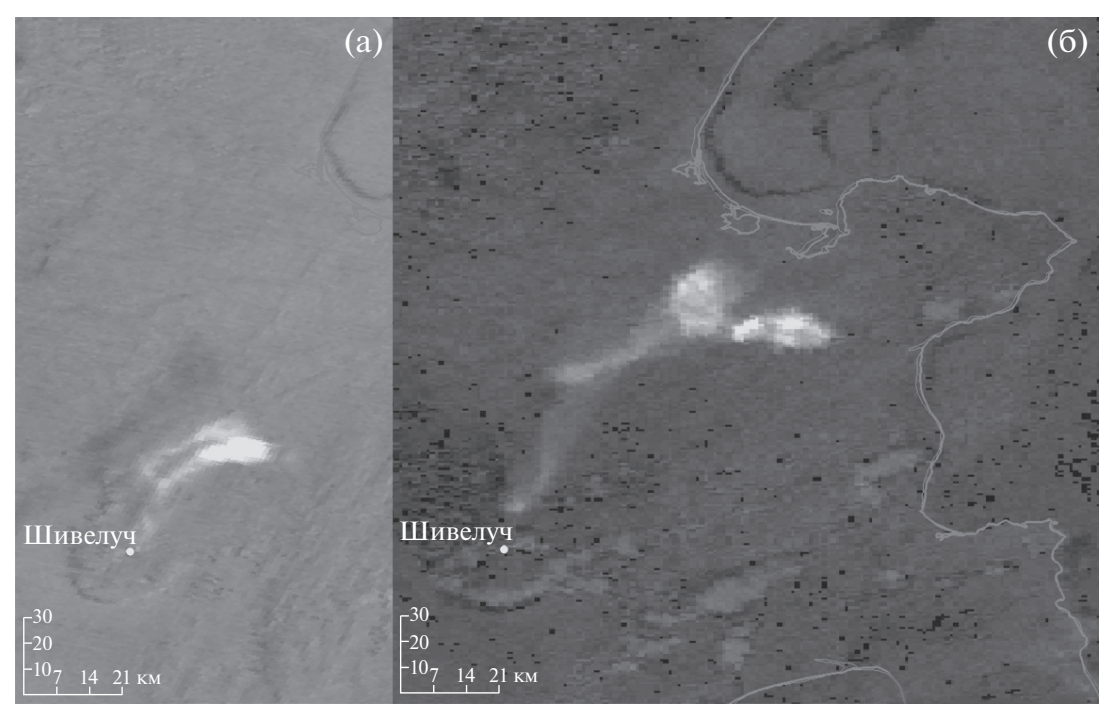

Рис. 2. Развитие с течением времени пеплового шлейфа вулкана Шивелуч 22 марта 2015 г. на спутниковых снимках. a - TERRA (00:41 UTC); б - NOAA № 19 (01:59 UTC). Данные из ИС VolSatView.

канов. Как и в случае пепловых шлейфов, температуры термальных аномалий в районах вулканов, полученные при обработке снимков с различных спутниковых приборов, показывают хорошую сопоставимость и однородность информации. Это важно для оперативного и ретроспективного анализа изменения температур и размеров термальных аномалий в районах вулканов, целью которого является предсказание будушей вулканической активности и снижение вулканоопасности для окрестных территорий. Например, известно, что постепенное (а иногда стремительное) увеличение размера и температуры термальной аномалии в районе лавового купола вулкана Безымянный (Камчатка) указывает на подготовку сильного эксплозивного извержения вулкана с выбросом пепла до 8-15 км н.у.м., опасного для авиации [Гирина, 2012; Schneider et al., 2000]. Обнаружение и оперативное отслеживание изменения параметров термальной аномалии в районе вулкана Безымянный по различным спутниковым данным не раз позволяло ученым из группы KVERT предсказывать такие его извержения и оповещать заинтересованных пользователей за неделю или за несколько часов до эксплозивного события [Гирина, 2012; Гордеев, Гирина, 2014].

Кроме этого, в ИС VolSatView созданы инструменты, позволяющие выделять пепловые облака и шлейфы, анализировать их временные серии, размещать их в базе данных с автоматическим расчетом площади пеплового шлейфа или облака, визуализировать пепловые шлейфы и облака по отдельным или всем вулканам за определенный период времени (рис. 3). Анализ изменения параметров пепловых шлейфов с течением времени дает возможность рассчитывать скорость их распространения и скорость приращения их площади. Например, после эксплозивного события на вулкане Шивелуч 22 ноября 2014 г. его пепловый шлейф отмечался на спутниковых снимках в течение 5 ч (рис. 4, табл. 2). Кромка пеплового шлейфа перемещалась со средней скоростью 59 км/ч, средняя скорость приращения площади пеплового

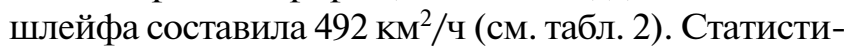
ческие данные о скорости перемещения пепловых облаков от вулканов и скорости приращения их площади позволят вовремя предупреждать заинтересованных пользователей о грозящих им пеплопадах, тем самым более верно оценивать вулканоопасность для различных территорий.

Наряду со спутниковыми данными среднего разрешения, в VolSatView для анализа и долгосрочного прогноза активности вулканов широко используется спутниковая информация высокого разрешения. Например, создан блок, ориентированный на работу с данными гиперспектрометра (ГC) Hyperion (High Resolution Hyperspectral Imager), установленного на спутнике EO-1 (http://EO1.usgs.gov). Прибор позволяет получать информацию в 242 спектральных каналах в диапазоне 0.4-2.5 мкм (видимый + ближний ИК-диапазоны) со спектральным разрешением 10 нм и пространственным разрешением 30 м. В ИС VolSatView сформирован и продолжает оперативно пополняться архив данных Hyperion по районам Камчатки и Курил с 2002 г. В VolSatView обеспечена возможность проводить как пространственный анализ данных ГС с использованием картографических интерфейсов сервиса, так и анализ спектральных профилей тех или иных объектов. Также можно выполнять сравнение разновременных данных и анализ данных ГС совместно с 


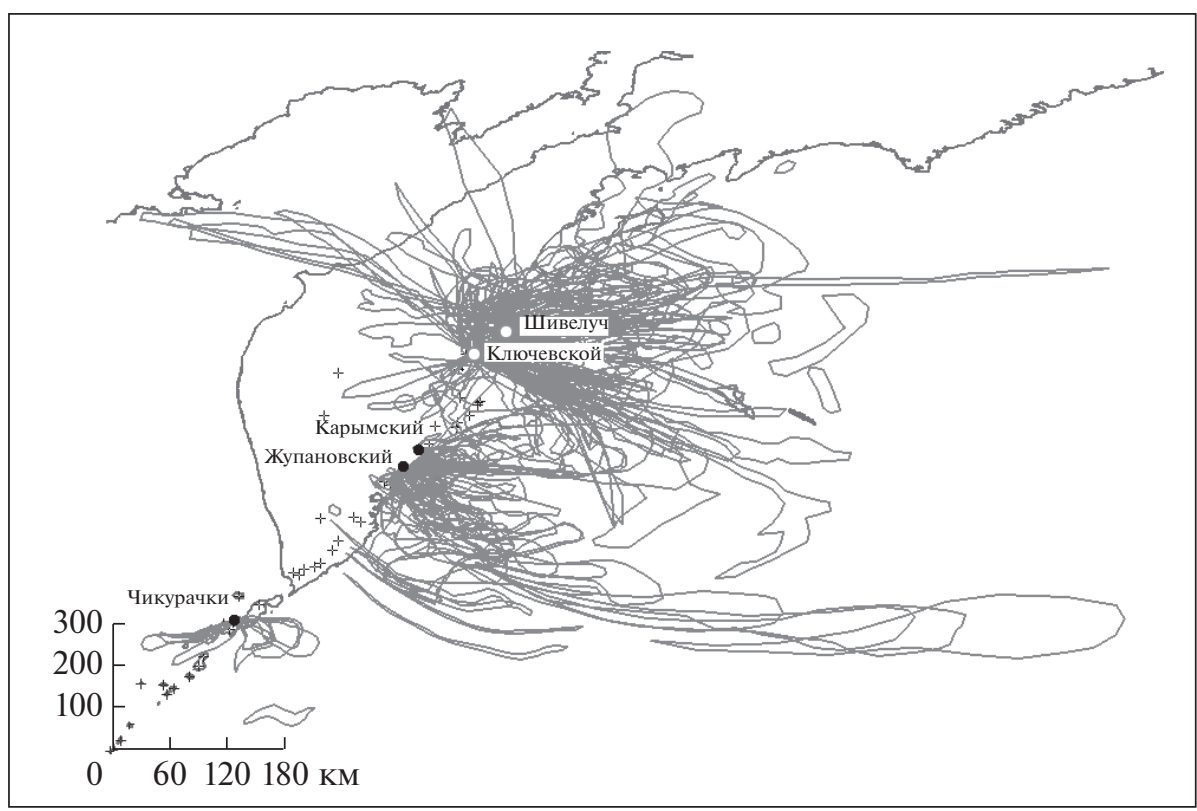

Рис. 3. Визуализация пепловых шлейфов и облаков, образовавшихся при эксплозивных извержениях вулканов Камчатки (Шивелуч, Ключевской, Карымский, Жупановский) и Северных Курил (Чикурачки) в 2013-2015 гг., выделенных по спутниковым снимкам ИС VolSatView.

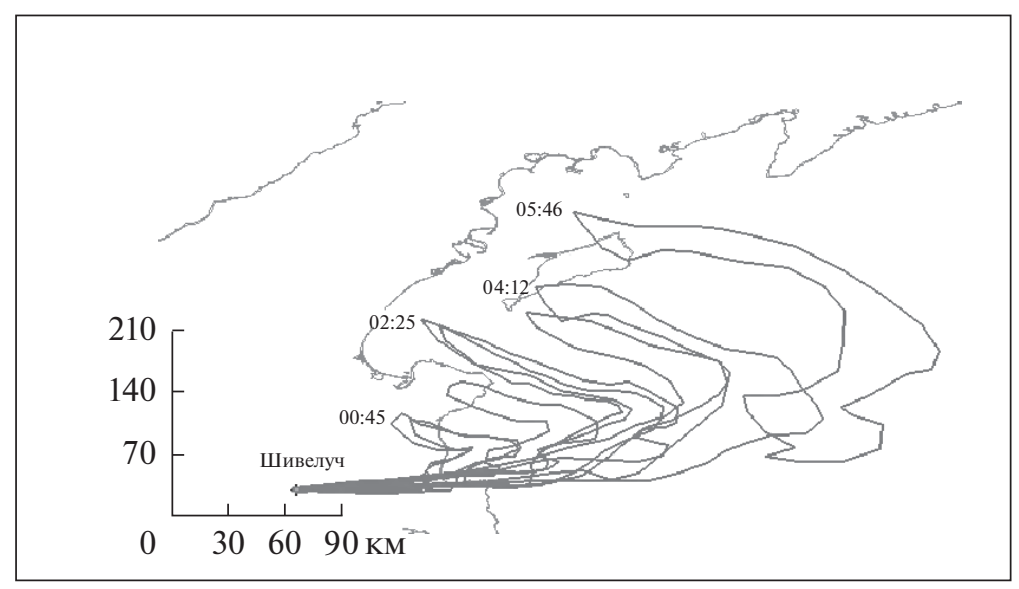

Рис. 4. Распространение с течением времени пеплового шлейфа вулкана Шивелуч после эксплозивного события в 22:21 UTC 22 ноября 2014 г. по данным ИС VolSatView.

другой информацией, имеющейся в системе [Гордеев и др., 2014, 2015].

Ocобое внимание в VolSatView уделяется средствам, позволяющим проводить совместный анализ информации, поступающей из разных спутниковых систем, источников наблюдения и результатов их анализа. Так, например, в системе можно провести синтез различных разновременных данных для выявления изменений, происходящих в районах вулканов. Также имеется возможность совместного представления информации о пепловых шлейфах, наблюдаемых на спутниковых снимках, и результатов численного моделирования распространения этих шлейфов.

\section{Технологии реализации системы}

Система VolSatView реализована и развивается на основе технологий и специализированного программного обеспечения, созданных в ИКИ РАН, ориентированных на разработку различных специализированных систем дистанционного мониторинга разных объектов и ресурсов [Андреев и др., 2004; Балашов и др., 2013; Егоров и др., 2004; Ефремов и др., 2004, 2012; Лупян и др., 2004, 
Таблица 2. Изменение с течением времени параметров пеплового шлейфа вулкана Шивелуч после эксплозивного события в 22:21 UTC 22 ноября 2014 г. по данным ИС VolSatView

\begin{tabular}{|c|c|c|c|c|c|c|}
\hline Спутник & $\begin{array}{c}23.11 .2014 . \\
\text { время } \\
\text { снимка, UTC }\end{array}$ & $\begin{array}{c}\text { Время } \\
\text { с начала } \\
\text { события, мин }\end{array}$ & $\begin{array}{c}\text { Протяжен- } \\
\text { ность } \\
\text { шлейфа, км }\end{array}$ & $\begin{array}{c}\text { Площадь } \\
\text { шлейфа, км²}\end{array}$ & $\begin{array}{c}\text { Скорость } \\
\text { распространения } \\
\text { шлейфа, км/ч }\end{array}$ & $\begin{array}{c}\text { Скорость } \\
\text { приращения } \\
\text { площади } \\
\text { шлейфа, км²/ ч }\end{array}$ \\
\hline AQUA & 0045 & 144 & 146.5 & 2825.4 & 61 & \\
\hline Suomi NPP & 0134 & 193 & 198.6 & 4441.8 & 62 & 502 \\
\hline AQUA & 0225 & 244 & 249.5 & 7156.0 & 61 & 667 \\
\hline Suomi NPP & 0311 & 290 & 286.0 & 9644.8 & 59 & 515 \\
\hline NOAA 18 & 0412 & 351 & 330.7 & 12455.5 & 56 & 480 \\
\hline NOAA 18 & 0546 & 445 & 422.4 & 14646.7 & 57 & 295 \\
\hline
\end{tabular}

2011; Толпин и др., 2011; Уваров и др., 2013, 2014]. Основной особенностью этих технологий и программного обеспечения является максимальная автоматизация процессов сбора, обработки, архивации и представления информации, используемой в системе. Это позволило минимизировать затраты на привлечение дополнительного технического персонала для обеспечения постоянного функционирования системы. В настоящее время поддержка системы осуществляется, в основном, силами ее разработчиков.

\section{ИНТЕГРАЦИЯ VOLSATVIEW С РАЗЛИЧНЫМИ ИНФОРМАЦИОННЫМИ СИСТЕМАМИ}

В ИС VolSatView реализованы технологии для оперативной работы с данными различных информационных систем, например, с данными группы KVERT (http://www.kscnet.ru/ivs/kvert/), ИС VOKКIA Геопортала ИВиС ДВО РАН (http://geoportal.kscnet.ru/volcanoes/) и автоматизированной ИС (АИС) Сигнал (http://signal.febras.net) [Ефремов и др., 2012; Романова, 2013; Романова и др., 2012; Сорокин и др., 2010; Ханчук и др., 2013; Korolev et al., 2015]. Это, например, позволяет непосредственно в VolSatView получать доступ к данным видеонаблюдений за вулканами Шивелуч, Ключевской, Горелый, Авачинский и др. (в настоящее время доступны данные с 10 видеокамер); информации об Авиационном цветовом коде опасности для авиации каждого из 36 вулканов; результатам моделирования траекторий распространения пепловых шлейфов от вулканов и т.д.

Для организации информационного взаимодействия перечисленных систем и поставки данных в VolSatView разработан специализированный сервис [Sorokin et al., 2014], который можно считать частью общей системы оперативного мониторинга вулканической активности в регионе. Возможность взаимного использования данных разных ИС приводит к повышению эффективности и качества наблюдений, а также к созданию новых информационных продуктов. В этом направлении решен ряд важных задач, например, после размещения Сообщения KVERT VONA об изменении Авиационного цветового кода опасности вулкана в базе данных ИС VOKKIA, в АИС Сигнал автоматически, по установленным шаблонам, меняется интервал съемки с видеокамер, направленных на этот вулкан.

Важной задачей снижения опасности для авиации при вулканических извержениях является прогнозирование изменения параметров пепловых шлейфов (их высоты и направления перемещения) в процессе их распространения в атмосфере. На сегодняшний день выполнена следуюшая задача: если при создании VONA указываются конкретные характеристики эксплозивного события (время начала эксплозии, высота выброса пепла, азимут распространения пеплового шлейфа) и они поступают в базу данных ИС VOKKIA, то в АИС Сигнал автоматически проводится расчет траектории распространения пеплового шлейфа, выполняемый с использованием модели Puff [Searcy et al., 1998] и алгоритмов PuffUAF, реализованных в Аляскинском университете в г. Фербенкс (University of Alaska Fairbanks - UAF) (https://www.uaf.edu/) (рис. 5).

\section{ВОЗМОЖНОСТИ VOLSATVIEW ДЛЯ МОНИТОРИНГА АКТИВНОСТИ ВУЛКАНОВ}

Для оперативного мониторинга вулканической активности важны не только обнаружение пеплового облака или шлейфа и оценка динамики их распространения, о чем указывалось выше 


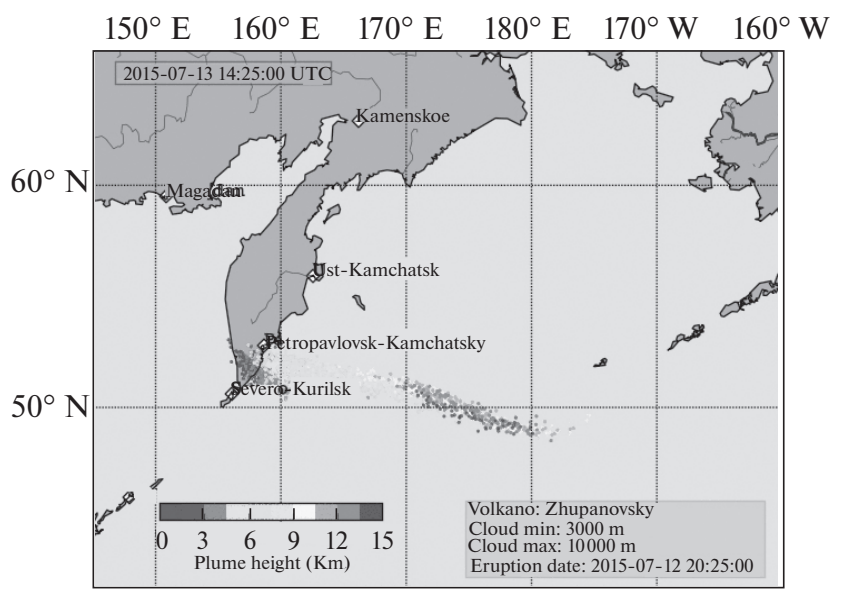

Рис. 5. Результаты моделирования распространения пеплового шлейфа от вулкана Жупановский 1213 июля 2015 г., выполненные по модели PuffUAF в АИС Сигнал ВЦ ДВО РАН.

(см. рис. 4, табл. 2), но и определение высоты над уровнем моря, на которой они перемещаются от вулканов. В картографическом интерфейсе VolSatView реализована возможность измерения в различных каналах температуры облаков и определение по атмосферному профилю их высоты (рис. 6). Параметры пепловых облаков и шлейфов (высота над уровнем моря; ширина и протяженность, направление перемещения от вулкана), измеренные в картографическом интерфейсе ИС VolSatView, непосредственно используются при составлении VONA KVERT для оповещения между- народного авиационного сообщества о появлении вулканоопасности для авиации (http://www.kscnet.ru/ivs/kvert/van/). Кроме этого, в системе внедрена и совершенствуется технология моделирования траекторий распространения пепловых шлейфов от вулканов, выполняемая на основе модели Puff и алгоритмов PuffUAF [Searcy et al., 1998] (расчет траекторий пепловых шлейфов производится в АИС Сигнал ВЦ ДВО РАН), основанная на оперативных и архивных спутниковых и метеорологических данных (направлении и скорости ветра в том числе), непрерывно поступающих в систему. ИС VolSatView позволяет визуализировать результаты расчетов траекторий перемещений пепловых шлейфов непосредственно на спутниковых снимках, на которых отмечаются эти шлейфы (рис. 7), в частности, таким образом можно оценивать степень достоверности выполненного моделирования. Отметим, что на спутниковом снимке (см. рис. 7) четко проявились конденсационные (инверсионные) следы от пролетевших недавно самолетов, то есть пепловый шлейф от вулкана Жупановский 12 июля 2015 г. пересек все главные авиатрассы и представлял определенную угрозу для полетов авиалайнеров.

Известно, что режим атмосферной циркуляции различных районов Камчатки чрезвычайно разнообразен. Для большей части полуострова характерна сезонная смена ветров, наиболее выраженная на его восточном побережье. В течение года в районе Камчатки проходит около 70 циклонов от Японии на Алеутские острова или в Берингово море [Кирьянов, 1992]. Наиболее выра-

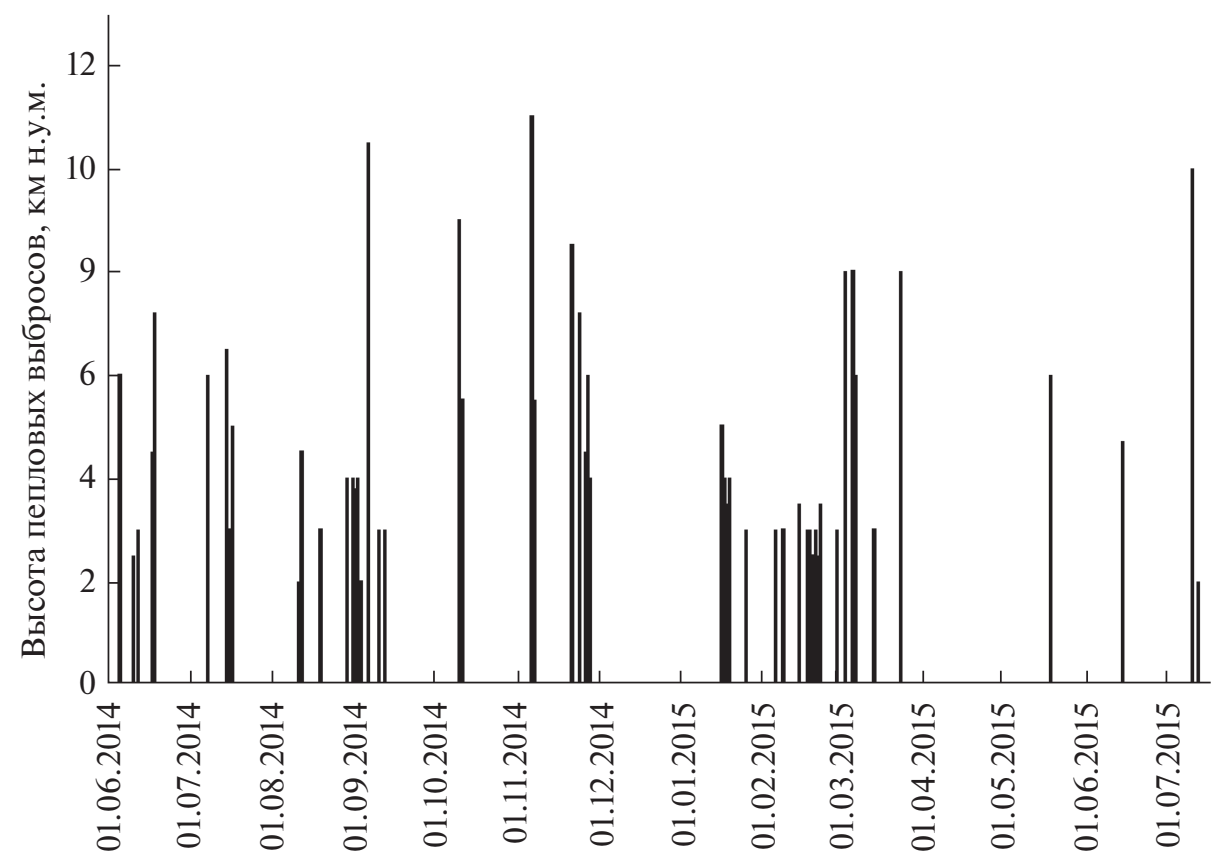

Рис. 6. Высота пепловых выбросов вулкана Жупановский в 2014-2015 гг. по спутниковым данным ИС VolSatView. 


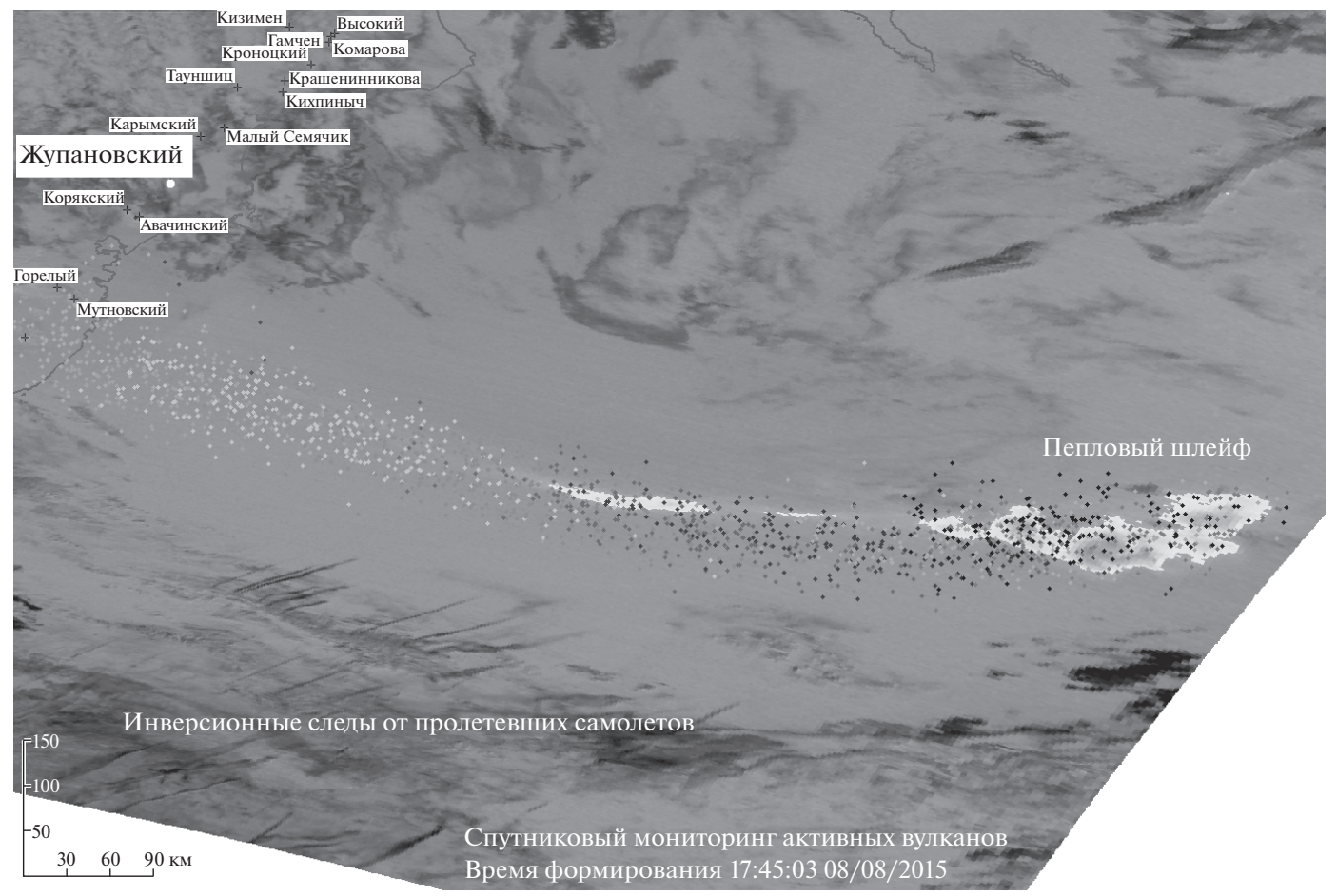

Рис. 7. Результаты моделирования распространения пеплового шлейфа от вулкана Жупановский 12 июля 2015 г., выполненные по модели PuffUAF в ИC VolSatView, визуализированные на спутниковом снимке MODIS (AQUA), 16:00 UTC, 12 июля 2015 г.

женные изменения величин скорости ветра, температуры, влажности наблюдаются в верхней тропосфере в районе тропопаузы, высота которой в районе полуострова меняется в течение года от 8 до 12 км. В работе [Кирьянов, 1992] показано, что для разных районов Камчатки у поверхности земли характерны различные направления ветров, но в стратосфере преобладает перенос воздушных масс в восточном и юго-восточном направлениях со скоростями 20-36 м/с. ИС VolSatView позволяет на современном уровне анализировать многочисленные данные о направлениях перемещения пепловых шлейфов от вулканов (конкретных Шивелуч, Ключевской, Карымский и др. или от всех одновременно) в течение их извержений, а также за определенный интервал времени (сезоны, годы) и т.д. Это важно для выявления закономерностей сезонного распространения пепловых шлейфов, анализа изменений скоростей перемещения пепловых шлейфов в течение десятилетий, в конечном итоге - для долгосрочного и оперативного прогноза опасности извержений вулканов для авиации.

Накопленный опыт американских и российских ученых по спутниковому мониторингу активных вулканов Камчатки позволяет с уверенностью оценивать их активность по параметрам (температуре и размеру) термальных аномалий [Гирина, 2012; Harris et al., 2000; Schneider et al., 2000 ; и др.]. Появление слабой термальной аномалии в районе вулкана всегда указывает на повышение его активности, и для часто извергающихся вулканов (Ключевской, Шивелуч, Безымянный, Карымский) она является отражением или предвестником эруптивных событий. Для редко извергающихся вулканов эпизодическое появление в районе вулкана слабой термальной аномалии указывает на повышение газовой эмиссии, иногда связанной с изменением метеорологических условий в районе; если аномалия на вулкане устойчиво фиксируется в течение суток, и ее температура и размер начинают увеличиваться - неизбежно произойдет сильное эксплозивное извержение. Во время продолжительных извержений вулканов, например, связанных с излиянием лавовых потоков, параметры термальных аномалий линейно связаны с количеством ювенильного вещества, поступающего на поверхность земли в момент их регистрации на спутниковом снимке [Гирина, 2012]. С окончанием эруптивной деятельности вулкана термальная аномалия постепенно сокращается, в межэруптивную фазу развития вулкана она может не регистрироваться. То есть термальная аномалия в 
районе вулкана является показателем его деятельности: состояние покоя, повышение активности, извержение. ИС VolSatView позволяет выявлять термальные аномалии в районах вулканов, в автоматическом и ручном режиме определять их размер и температуру, размещать информацию в базе данных [Ефремов и др., 2013, 2013а].

При ретроспективном анализе деятельности вулканов важно учитывать все параметры их активности: изменения с течением времени температуры и размера термальных аномалий в районах активных вулканических аппаратов для выявления предвестников извержений; приуроченность термальных аномалий к определенным структурам: лавовым куполам, лавовым потокам, пирокластическим потокам, обвалам лавовых куполов или активных вулканов и т.д.; зональность распределения температур в пределах аномалий для оценки степени опасности грядущего или продолжающегося извержения вулкана [Гирина, 2012; Carter et al., 2008; Oppenheimer, Francis, 1997; и др.].

ИС VolSatView позволяет проводить комплексный анализ любых вулканогенных объектов, расположенных в районе вулкана, оценивать их состояние и прогнозировать будущую вулканическую активность. Например, в октябре 2013 г. проснулся вулкан Жупановский, расположенный в 70 км от г. Петропавловск-Камчатский (последнее его извержение происходило в 1956-1957 гг. [Сирин, 1958]), и после четырехдневной умеренной фреатической эруптивной активности успокоился [Гирина, Ненашева, 2015; VONA KVERT 2013-25]. 6 июля 2014 г. началось сильное эксплозивное извержение вулкана, которое с перерывами продолжалось до марта 2016 г. [VONA KVERT 2016-22]. Сильные эксплозивные события 12 и 14 июля [VONA KVERT 2015-179; VONA KVERT 2015-181], а также 27 и 30 ноября [VONA KVERT 2015-210; VONA KVERT 2015-211], спровоцировали обвал части активного конуса Приемыш вулкана Жупановский. Обвальные отложения у подножия вулкана, образовавшиеся 12 и 14 июля, были обнаружены 16 июля 2015 г. [Горбач и др., 2015].

На снимке TERRA Aster (NASA, JPL) (11:23 UTC, 13 июля 2015 г.) на поверхности средней части обвальных отложений была отмечена термальная аномалия площадью 3.7 км², температура которой варьировалась от 9.5 до $15^{\circ} \mathrm{C}$. На снимке высокого разрешения, полученном 26 июля 2015 г. со спутника Метеор-М № 2, хорошо выделяются две ветви обвальных отложений, общая площадь которых составляет около 18-20 км² (рис. 8а). Анализ фотографий обвала от 16 июля 2015 г., снимков Landsat-8 до извержения вулкана, а также снимков Метеор-M № 2 и Landsat-8 после извержения показал, что средняя мощность отло- жений обвала не превышает 2 м, следовательно, объем их оценивается в $0.04 \mathrm{KM}^{3}$.

Проведенная в ИС VolSatView классификация обвальных отложений с использованием данных прибора КМСС [Кондратьева и др., 2015], установленного на спутнике Метеор-М № 2, полученных 26.07.2015 (см. рис 8а), позволяет выявить несколько характерных участков на этих образованиях (см. рис 8б). Детальный анализ спектральных характеристик этих участков был проведен с использованием данных прибора Hyperion (спутник ЕО-1), полученных 24.07.2015. Графики спектральной отражательной способности (COC) по осредненным наборам тестовых точек, принадлежащим разным выделенным участкам обвальных отложений, приведены на рис 8в.

Анализ графиков СОС показывает, что наименьшая величина СОC (0.09-0.13) присуща участку темно-серого цвета, наибольшая (0.14$0.20)$ - участку черного цвета, для области светлосерого цвета СОС имеет промежуточные значения (0.11-0.17) (см. рис. 8в). Следует отметить, что светло-серое поле распространяется на все отложения обвала, черное - на большую часть левой ветви и центральную часть правой (см. рис. 8б). Вероятно, большая часть отложений сформировалась в процессе или в конце высокой эксплозивной активности (аномалия на снимке Aster - отложения направленных выбросов из кратера Приемыш?) вулкана Жупановский 12 июля 2015 г. (участки обвала светло- и темносерого цвета на рис. 8б). Горячий материал эксплозий обрушивался на ледники и снежники, растапливал их, и водонасыщенные рыхлые образования обвала (оползня-обвала?) с большим содержанием тонких частиц и со следами течения на поверхности покрыли широким плащом подножие вулкана. Из разрушенного сектора конуса Приемыш 14 июля дополнительно обрушился относительно сухой (возможно теплый) грубообломочный материал, отложившийся в основном на левой ветви обвала 12 июля. Косвенным подтверждением формирования грубообломочной массы обвала 14 июля 2015 г. является сообщение KVERT о пепловом облаке, перемещавшемся на юго-запад и затем на восток-юго-восток от вулкана на высоте не более 2 км н.у.м. [VONA KVERT 2015-181]. Различия в гранулометрическом составе, водонасыщенности, температуре обвальных отложений 12 и 14 июля обусловили разницу структур этих образований и, соответственно, величин их СОС (см. рис. 8в).

\section{ЗАКЛЮЧЕНИЕ}

ИС VolSatView, созданная в 2011 г., за пять лет развития превратилась в мощный инструмент для оперативного мониторинга и ретроспективного изучения вулканов Камчатки и Курил. Изначаль- 
(a)

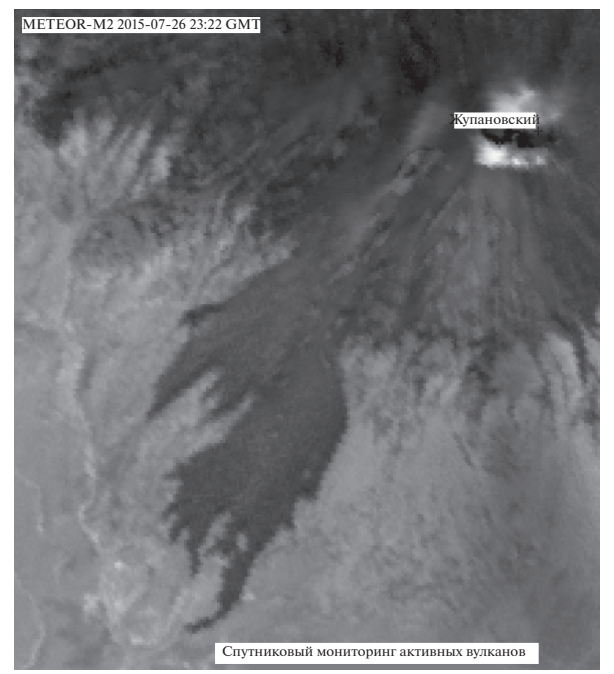

(б)

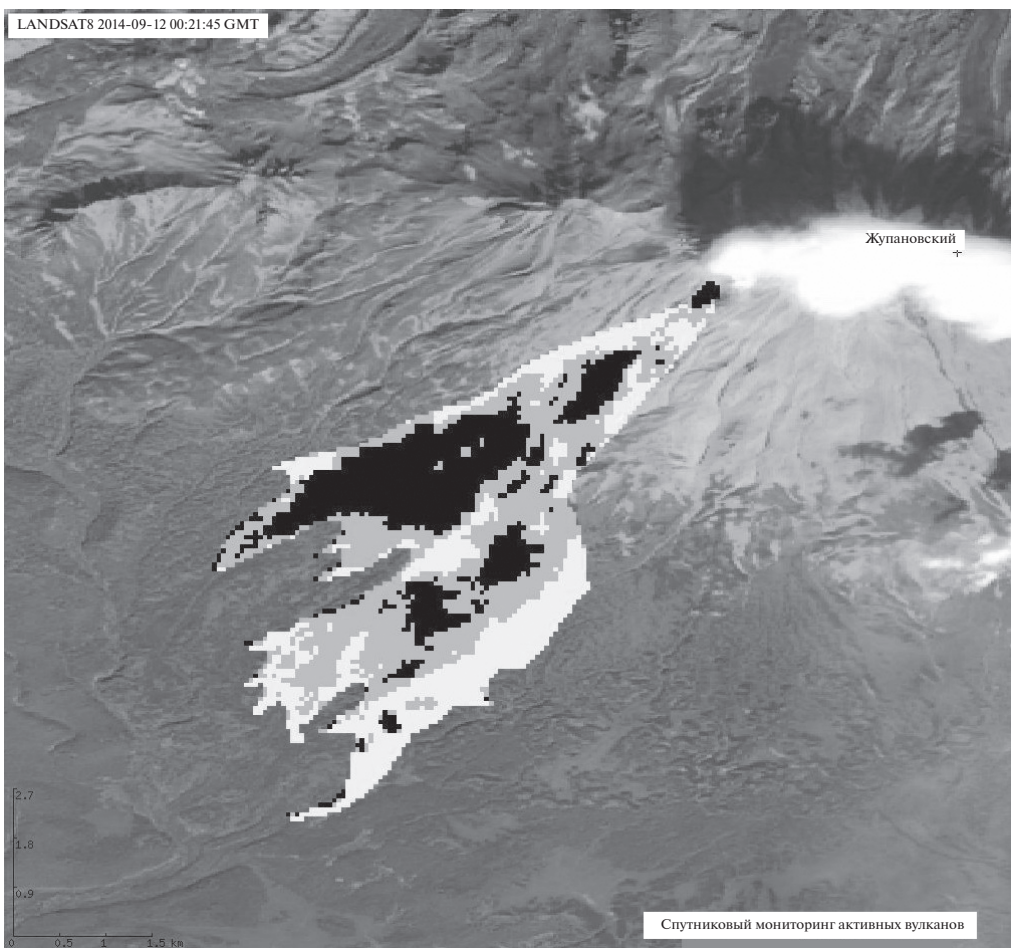

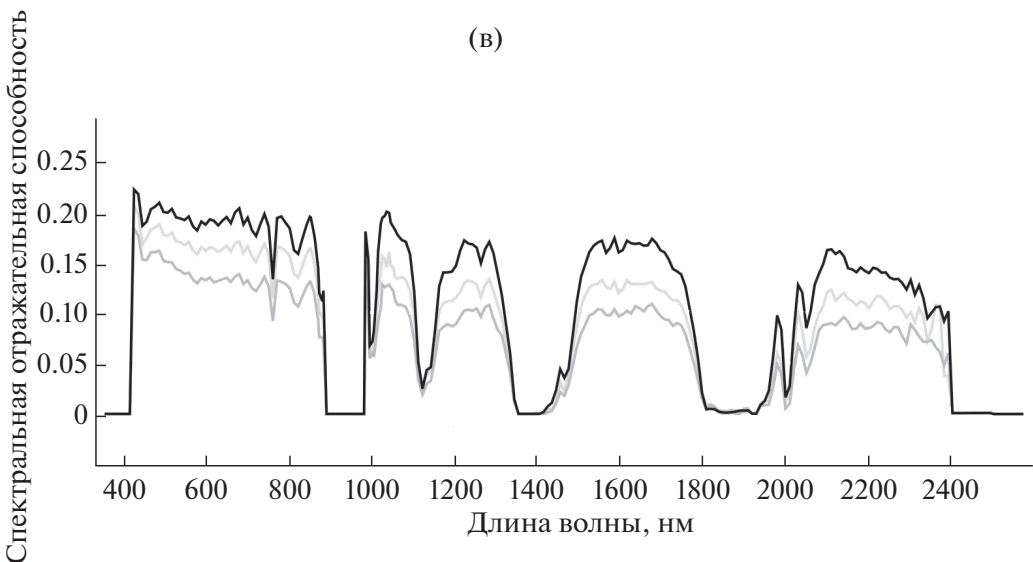

Рис. 8. Результат анализа отложений обвала вулкана Жупановский, образовавшихся 12-14 июля 2015 г., полученный средствами ИС VolSatView.

а - изображение района обвальных отложений 26.07.2015. (спутник Метеор-М № 2, прибор КМСС); б - классификация обвальных отложений, выполненная по данным прибора КМСС на фоне изображения в панхроматическом канале прибора OLI-TIRS (спутник Landsat 8) 12.09.2014; в - графики осредненных СОС участков обвальных отложений по данным прибора Нyperion (спутник EO-1) 24.07.2015. (цвета линий на графике соответствуют цвету участков обвальных отложений, выделенных по данным прибора КМСС) (см. описание в тексте).

но ориентированная на свободно распространяемые некоммерческие спутниковые данные, ИС VolSatView в настоящее время обладает возможностями автоматизированного сбора различных спутниковых данных среднего и высокого разрешения с максимальной частотой их поступления в систему и удаленной (распределенной) работы с ними, а также возможностью совместного анали- за спутниковых и иных инструментальных и научных данных (например, метео-, видео-, результатов математического моделирования и т.п.), поступающих из других ИС.

В VolSatView реализован широкий набор инструментов для работы как с рядами спутниковых наблюдений, так и с картографической информацией. Например, непосредственно в web-интер- 
фейсе системы доступны инструменты анализа полей температуры, позволяющие мгновенно просматривать значения температуры в каждой точке снимка, что значительно сокращает время анализа термальных аномалий в районах действующих вулканов. Созданы инструменты для выделения пепловых облаков и шлейфов, анализа их временных серий, автоматического расчета площади пеплового шлейфа или облака, визуализации пепловых шлейфов и облаков по отдельным или всем вулканам за определенный период времени.

B VolSatView для ретроспективного анализа и прогноза будущей активности вулканов широко используется спутниковая информация высокого разрешения. Например, обеспечена возможность проводить пространственный анализ гиперспектральных данных (Hyperion, EO-1) с использованием картографических интерфейсов системы и анализ спектральных профилей тех или иных объектов; выполнять сравнение и анализ разновременных гиперспектральных данных совместно с другой информацией, имеющейся в системе.

В ИС VolSatView реализованы технологии для оперативной работы с данными различных ИС: информацией группы KVERT в ИC VOKKIA Геопортала ИВиС ДВО РАН, АИС Сигнал и др. Например, непосредственно в VolSatView можно получать доступ к данным видеонаблюдений за вулканами Шивелуч, Ключевской, Горелый, Авачинский и др.; информации об Авиационном цветовом коде каждого из 36 вулканов; результатам моделирования траекторий распространения пепловых шлейфов от вулканов - можно одновременно визуализировать информацию о пепловых шлейфах, наблюдаемых на спутниковых снимках, и результаты численного моделирования распространения этих шлейфов; и т.д.

Основываясь на опыте KVERT, с 2014 г. сотрудники группы SVERT (Sakhalin Volcanic Eruption Response Team) Института морской геологии и геофизики ДВО РАН также применяют ИС VolSatView для мониторинга и исследования вулканов Курильских островов.

Перспективными направлениями развития ИС VolSatView являются следующие:

- расширение спектра данных, поступающих от новых спутниковых приборов (например, Ресурс-П, Himawari-8 и др.);

- определение в оперативном режиме высоты пепловых выбросов и распространения пепловых шлейфов по имеющимся в системе метеоданным;

- расширение возможностей проведения классификаций вулканогенных отложений по различным спутниковым данным высокого разрешения;

- создание возможности 3-D моделирования распространения пепловых шлейфов от вулканов во время извержений.
Работа выполнена при поддержке проекта РНФ (№ 16-17-00042).

\section{СПИСОК ЛИТЕРАТУРЫ}

Андреев М.В., Ефремов В.Ю., Лупян Е.А. и др. Построение интерфейсов для организации работы с архивами спутниковых данных удаленных пользователей // Современные проблемы дистанционного зондирования Земли из космоса. 2004. № 1. С. 514-520.

Балашов И.В., Халикова О.А., Бурцев М.А. и др. Организация автоматического получения наборов информационных продуктов из центров архивации и распространения спутниковых и метеоданных // Современные проблемы дистанционного зондирования Земли из космоса. 2013. Т. 10. № 3. С. 9-20.

Гирина O.A. 15 лет деятельности Камчатской группы реагирования на вулканические извержения // Материалы конференции, посвященной Дню вулканолога, Петропавловск-Камчатский, 27-29 марта 2008 г. Петропавловск-Камчатский: ИВиС ДВО РАН, 2008. C. 52-59.

Гирина O.A. Камчатской группе реагирования на вулканические извержения (KVERT) - 20 лет // Вулканизм и связанные с ним процессы. Материалы региональной конференции, посвященной Дню вулканолога, 28-29 марта 2013 г. Петропавловск-Камчатский: ИВиС ДВО РАН, 2014. С. 36-41.

Гирина О.A. О предвестнике извержений вулканов Камчатки, основанном на данных спутникового мониторинга // Вулканология и сейсмология. 2012. № 3. C. 14-22.

Гирина О.А., Гордеев Е.И. Проект KVERT - снижение вулканической опасности для авиации при эксплозивных извержениях вулканов Камчатки и Северных Курил // Вестник ДВО РАН. 2007. № 2. С. 100-109.

Гирина О.А., Ненашева Е.М. Извержения вулкана Жупановский в 2013-2015 гг. // Отчизны верные сыны. Материалы XXXII Крашенинниковских чтений. Петропавловск-Камчатский: Камчатская краевая научная библиотека им. С.П. Крашенинникова, 2015. С. 172174.

Горбач Н.В., Самойленко С.Б., Плечова А.А., Мельни$\kappa о в$ Д. В. Обвал на вулкане Жупановский (Камчатка) в июле 2015 г.: первые данные и наблюдения // Вестник КРАУНЦ. Сер. Науки о Земле. 2015. № 1. Вып. 25. C. 231-238.

Гордеев Е.И., Гирина О.А. Вулканы и их опасность для авиации // Вестник Российской академии наук. 2014. T. 84. № 2. C. 134-142. doi 10.7868/S0869587314020121

Гордеев Е.И., Гирина О.А., Лупян Е.А. и др. Возможности использования данных гиперспектральных спутниковых наблюдений для изучения активности вулканов Камчатки с помощью геопортала VolSatView // Coвременные проблемы дистанционного зондирования Земли из космоса. 2014. Т. 11. № 1. С. 267-284.

Гордеев Е.И., Гирина О.А., Лупян Е.А. и др. Изучение продуктов извержений вулканов Камчатки с помощью гиперспектральных спутниковых данных в информационной системе VolSatView // Современные проблемы дистанционного зондирования Земли из космоса. 2015. T. 12. № 1. C. 113-128. 
Егоров В.А., Ильин В.О., Лупян Е.А. и др. Возможности построения автоматизированных систем обработки спутниковых данных на основе программного комплекса XV_SAT // Современные проблемы дистанционного зонддирования Земли из космоса. 2004. № 1. C. 431-436.

Ефремов В.Ю., Гирина О.А., Крамарева Л.С. и др. Создание информационного сервиса "Дистанционный мониторинг активности вулканов Камчатки и Курил” // Современные проблемы дистанционного зондирования Земли из космоса. 2012. Т. 9. № 5. С. 155-170.

Ефремов В.Ю., Лупян Е.А., Мазуров А.А. и др. Технология построения автоматизированных систем хранения спутниковых данных // Современные проблемы дистанционного зондирования Земли из космоса. 2004. № 1. C. 437-443.

Ефремов В.Ю., Лупян Е.А., Матвеев А.М. и др. Возможности анализа температурных аномалий на вулканах в спутниковом сервисе VolSatView // Современные проблемы дистанционного зондирования Земли из космоса. Тезисы докладов. Одиннадцатая Всероссийская открытая ежегодная конференция, 11-15 ноября 2013 г., Москва. М.: ИКИ РАН, 2013. С. 304

Ефремов В.Ю., Лупян Е.А., Матвеев А.М. и др. Организация работы со спутниковыми данными для решения задач дистанционного мониторинга активности вулканов Камчатки и Курил на примере спутникового сервиса VolSatView // Труды Четвертой научно-технической конференции "Проблемы комплексного геофизического мониторинга Дальнего Востока России”, 30 сентября-4 октября 2013 г., г. Петропавловск-Камчатский. Обнинск: ГС РАН, 2013а. С. 45-48.

Кирьянов В.Ю. Вулканические пеплы Камчатки как источник потенциальной опасности для пассажирских авиалиний // Вулканология и сейсмология. 1992. № 3. С. $16-36$.

Кирьянов В.Ю., Чубарова О.С., Гирина О.А. и др. Группа по обеспечению безопасности полетов от вулканических пеплов (КВЕРТ): 8 лет деятельности // Геодинамика и вулканизм Курило-Камчатской островодужной системы. Петропавловск-Камчатский: ИВГиГ ДВО РАН, 2001. C. $408-423$.

Кондратьева Т.В., Жуков Б.С., Полянский И.В., Фори А.А. Сопоставление коэффициентов яркости природных объектов по данным КМСС на КА “Метеор-М” № 1 и MODIS на KA "Terra" // Современные проблемы дистанционного зондирования Земли из космоса. 2015. T. 12. № 1. С. 215-224.

Лупян Е.А., Мазуров А.А., Назиров Р.Р. и др. Технология построения автоматизированных информационных систем сбора, обработки, хранения и распространения спутниковых данных для решения научных и прикладных задач // Современные проблемы дистанционного зондирования Земли из космоса. 2004. № 1. С. 81-88.

Лупян Е.А., Мазуров А.А., Назиров Р.Р. и др. Технологии построения информационных систем дистанционного мониторинга // Современные проблемы дистанционного зондирования Земли из космоса. 2011. Т. 8. № 1. С. $26-43$.

Лупян Е.А., Милехин О.Е., Антонов В.Н. и др. Система работы с объединенными информационными ресурсами, получаемыми на основе спутниковых данных в центрах НИЦ Планета // Метеорология и гидрология. 2014. № 12. С. 89-97.

Романова И.М. Геопортал ИВиС ДВО РАН как единая точка доступа к вулканологическим и сейсмологическим данным // Геоинформатика. 2013. № 1. С. 46-54. Романова И.М., Гирина О.А., Максимов А.П., Мелекесиев И.В. Создание комплексной информационной веб-системы "Вулканы Курило-Камчатской островной дуги" (VOKKIA) // Информатика и системы управления. 2012. № 3. Вып. 33. С. 179-187.

Сирин А.Н. Состояние некоторых вулканов Камчатки в начале 1957 г. // Бюлл. вулканол. станций. 1958. № 27. C. 16-24.

Сорокин А.А., Королев С.П., Михайлов К.В., Коновалов А.В. Автоматизированная информационная система оценки состояния сети инструментальных сейсмологических наблюдений "Сигнал-С” // Информатика и системы управления. 2010. № 4 (26). С. 161-167.

Толпин В.А., Балашов И.В., Ефремов В.Ю. и др. Создание интерфейсов для работы с данными современных систем дистанционного мониторинга (система GEOSMIS) // Современные проблемы дистанционного зондирования Земли из космоса. 2011. Т. 8. № 3. С. 93-108.

Уваров И.А., Матвеев А.М., Бурцев М.А. и др. Организация распределенной работы с данными спутниковых гиперспектральных наблюдений для решения научных и прикладных задач // Современные проблемы дистанционного зондирования Земли из космоса. 2014. Т. 11. № 1. С. 322-333.

Уваров И.А., Халикова О.А., Балашов И.В. и др. Организация работы с метеорологической информацией в информационных системах дистанционного мониторинга // Современные проблемы дистанционного зондирования Земли из космоса. 2013. Т. 10. № 2. С. $30-45$.

Ханчук, А.И. Сорокин А.А., Смагин С.И. и др. Развитие информационно-телекоммуникационных систем в ДВО РАН // Информационные технологии и вычислительные системы. 2013. № 4. С. 45-57.

Carter A.J., Girina O.A., Ramsey M.S., Demyanchuk Y.V. ASTER and field observations of the 24 December 2006 eruption of Bezymianny Volcano, Russia // Remote Sensing of Environment. 2008. V. 112. P. 2569-2577.

Harris A.J.L., Flynn L.P., Dean K.G. et al. Real-time monitoring of volcanic hot spots, in remote sensing of active volcanism // AGU Monograph. 2000. V. 116. P. 139-159.

Khanchuk A.I., Smagin S.I., Sorokin A.A., Makogonov S.V. Regional Network of the Far Eastern Branch of RAS // First Russia and Pacific Conference on Computer Technology and Applications (Russia Pacific Computer 2010), 6-9 September, 2010; Russian Academy of Sciences, Far Eastern Branch, Vladivostok, Russia, 2010. P. 233-234.

Korolev S.P., Sorokin A.A., Verkhoturov A.L. et al. Automated Information System for Instrument Data Processing of the Regional Seismic Observation Network of FEB RAS // Seismic Instruments. 2015. V. 51. № 3. P. 209-218.

Miller T.P., Casadevall T.J. Volcanic ash hazards to aviation // Encyclopedia of Volcanoes. Academic Press, San Diego, California. 2000. P. 915-930.

Neal Ch., Girina O., Senyukov S. et al. Russian eruption warning systems for aviation // Natural Hazards. Springer Netherlands. 2009. V. 51. № 2. P. 245-262. 
Oppenheimer C., Francis $P$. Remote sensing of heat, lava and fumarole emission from Erta 'Ale volcano, Ethiopia // Int. J. Rem. Sens. 1997. V. 18. P. 1661-1692.

Schneider D.J., Dean K.G., Dehn J. et al. Monitoring and Analyses of Volcanic Activity Using Remote Sensing Data at Study for Kamchatka, Russia, December 1997 // Remote Sensing of Active Volcanism. Geophysical Monograph. 2000. P. 65-85.

Searcy $C$., Dean K., Stringer $W$. PUFF: a high-resolution volcanic ash tracking model // J. of Volcanol. and Geotherm. Res. 1998. 80. P. 1-16.

Sorokin A.A., Korolev S.P., Romanova I.M. et al. RESTful Web Service for Kamchatka Volcanoes Observations // Modern Information Technologies in Earth Sciences. Pro- ceedings of the International Conference. September 8-13, 2014, Petropavlovsk-Kamchatsky. Vladivostok: Dalnauka. 2014. P. 155.

VONA KVERT 2013-25: http://www.kscnet.ru/ivs/kvert/ van/index.php?n=2013-25.

VONA KVERT 2015-179: http://www.kscnet.ru/ivs/kvert/ van/index.php? $\mathrm{n}=2015-179$.

VONA KVERT 2015-181: http://www.kscnet.ru/ivs/kvert/ van/index.php?n=2015-181.

VONA KVERT 2015-211: http://www.kscnet.ru/ivs/kvert/ van/index.php? $\mathrm{n}=2015-211$.

VONA KVERT 2016-22: http://www.kscnet.ru/ivs/kvert/ van/index.php?n=2016-22. 